\title{
Who rallies around the flag? Evidence from panel data during the Covid-19 pandemic
}

\author{
Sven Hegewald \& Dominik Schraff ${ }^{1}$
}

\begin{abstract}
Recent studies on political trust during the Covid-19 pandemic diagnosed a rally around the flag effect, leading to exceptionally high levels of trust in politics. While this finding has been established over various country-contexts, our understanding of the precise dynamics behind the rally effect remains limited. In this paper, we argue that health and economic risks, as well as partisanship condition the rally effect. Using individual-level panel data from the Netherlands, covering the time before and during the first Covid-19 wave, we show that the rally effect is particularly pronounced among older individuals, while it is absent among the young. Furthermore, we find a catch-up effect among the more distrusting part of the population, such as populist supporters and low-income earners, who largely drive the rally effect. This leads to a convergence of trust across different ideational and economic subpopulations, providing for a silver lining during otherwise turbulent times.
\end{abstract}

Keywords: COVID-19; panel data; political trust; rally effect

${ }^{1}$ Center for Comparative and International Studies, ETH Zürich, Haldeneggsteig 4, 8092 Zürich, Switzerland 


\section{Introduction}

Many policy measures to contain the Covid-19 pandemic impose strong constrains on individual freedoms and rights. Against this backdrop, consent and compliance with pandemic policies critically hinge on citizens' confidence in political institutions (Marien \& Hooghe, 2011; Marien \& Werner, 2019). Therefore, a basic level of trust in the integrity of the political system may be regarded as a fundamental prerequisite for a successful policy response to the Covid19 crisis. In this paper, political trust is understood as a form of diffuse support for public institutions (Easton, 1975). As trust is relational, individuals are vulnerable to other individuals, groups, or institutions that have the capacity to betray the trust invested in them (Hardin, 2000; Levi \& Stoker, 2000). In this regard, the perceived legitimacy and competence of public institutions is a central indicator of the degree of trust that binds citizens to their political system.

In response to the Covid-19 pandemic, public support for government action has been exceptionally high across many democratic societies. Research on the impact of the Covid-19 crisis suggests a sharp increase in citizens' diffuse political support, diagnosing a rally around the flag effect of the pandemic on political trust (Devine et al., 2020). However, while research over manifold country-contexts confirms this finding (Bol et al., 2020), we still have a very limited understanding of how the rally effect actually works. More specifically, a lack of systematic evidence on who rallies around the flag constrains our knowledge about the people that might be more or less likely to comply with political measures to contain the pandemic.

We addresses this gap by analyzing individual-level panel data among a sample of around 1,800 respondents that covers the time before and during the first Covid-19 wave in the Netherlands. This data structure allows us to track individual-level changes in political trust 
when the first Covid-19 wave hit and thereby makes it possible to identify individual-level differences in people's responses to the pandemic. Theoretically, we argue that individuals might react differently to the Covid-19 crisis as a result of differences in potential risk exposure. In particular, we suggest that rallying around political institutions varies along the possible health and economic risks induced by the crisis. Moreover, we propose that rally effects should differ across populist and non-populist voters, as populist voters start from very different baseline levels of trust when entering the pandemic.

The results of our analysis lend credence to these arguments. First, we show that the rally effect is strongly pronounced among older respondents, while it is absent among the young. We explain this by the asymmetric distribution of costs and benefits from pandemic policies across age groups. Second, we find that individuals belonging to subpopulations generally characterized by lower trust in politics, such as low-income individuals or populist voters, exhibit the highest leap in political trust, leading trust levels to converge across these subpopulations. We therefore conclude that the rally effect during the Covid-19 pandemic is largely driven by traditionally low trusting individuals surrendering their skeptical stance towards politics, when confronted with a societal threat requiring decisive collective action.

The remainder of this paper proceeds in the following way. After reviewing the existing literature identifying a rally effect during the pandemic, we illustrate how this dynamic might differ at the individual-level. We then present our panel data, method and results. We conclude by outlining some broader implications of our findings, suggesting that in particular the convergence of trust we observe might represent a beacon of hope during otherwise turbulent times. However, we also highlight the difficult situation of the young and underline that our evidence presents first age-based cracks in the societal response to the pandemic. 


\section{Political trust during the pandemic: A rally effect}

Early research on the impact of the Covid-19 pandemic observes a surge in citizens' diffuse political support, mainly due to people's satisfaction with the respective government responses (Baekgaard et al., 2020; Bol et al., 2020). In short, this body of studies suggests that this so-called rally effect is rather homogenous across the population, lasts over an extended time period of several weeks, and expands to public institutions that are not directly involved in crisis management, such as parliaments and courts (Baekgaard et al., 2020). Moreover, the rally effect is found to go beyond individual evaluations of the political system and its institutions. For instance, evidence from Canada demonstrates decreasing political polarization as Covid-19 cases rose (Merkley et al., 2020). Furthermore, a study from Germany shows a boost in government voting over the course of the pandemic (Leininger \& Schaub, 2020). In a similar vein, Bol et al. (2020) argue that lockdown measures across Europe have found approval among voters, rewarding political institutions with increased trust. In this sense, this literature follows a more general argument on how citizens rationally reward political institutions for swift crisis relief (Bechtel \& Hainmueller, 2011). Indeed, this mechanism is further substantiated by evidence from a field experiment conducted in Spain, suggesting that people tend to switch to a strong preference for unified and technocratic governance in reaction to the pandemic (Amat et al., 2020). These studies maintain that the rally effect on political trust is rooted in a rational response of the public to support policy measures issued by governments to fight the crisis.

Another set of recent works agrees with the empirical diagnosis of a rally effect, but does more strongly rely on psychological arguments to explain it. Essentially, these accounts suggest systematic differences across countries and individuals when it comes to risk perceptions in the Covid-19 pandemic (Dryhurst et al., 2020). Following that, some rally effect studies build 
on psychological mechanisms to argue that the extent of anxious arousal shapes the way people rally around political institutions (Esaiasson et al., 2020). This is supported by the findings that standard explanations of political trust, such as economic perceptions, lost relevance as the pandemic spread (Schraff, 2020). Such psychological accounts are further supported by psychological research, which shows increased anxious arousal as a response to the existential threat posed by Covid-19 (Tabri et al., 2020). Besides the anxious arousal mechanism, these psychological accounts also imply that partisanship might shape individual reactions to the pandemic. Here, evidence from the US suggests that partisan biases play an important role when it comes to compliance with Covid-19 policies (Goldstein \& Wiedemann, 2020).

Following these arguments, one should expect that the rally effect is not homogenous across society. First, people most likely vary in their emotional response to the pandemic. Second, people have very different perceptions and believes about society and political institutions. As the pandemic hits, its risks as well as the political measures enacted to contain it, are likely evaluated in light of these pre-existing believes. We therefore expect that there is plenty of room for systematic research on individual-level effect heterogeneity in the rally effect. In this paper, we focus on two salient dimensions that seem particularly plausible given the existing body of studies. We expect that the individual health and economic risks associated with the pandemic determine the extent of the rally effect. In addition to that, we propose that partisan biases will likewise determine the effect of the pandemic on political trust. The next section outlines our arguments on these potential sources of effect heterogeneity. 


\section{Who rallies around the flag?}

\section{Health risks}

The Covid-19 pandemic produces an asymmetric distribution of risks and costs across the population. This asymmetry is probably most pronounced across age groups. Older people face substantially higher health risks from the Corona virus, not only because of age per se, but also due to the chronic diseases that become more frequent with higher age (Zheng et al., 2020). Older people, therefore, might be more willing to bear the costs of preventive Covid19 policies, such as restrictions to public life and free movement. Because of that, older generations see a stronger need to rally around the political institutions that provide these preventive measures. Young people, in contrast, face a much lower risk of serious illness from the virus. Moreover, younger citizens might perceive higher costs from lockdown measures since they are usually more mobile and socially active. In this regard, school closures and the restriction of leisure activities constitute a major disruption for young people's lives. Indeed, young people are frequently hit harder by lockdown measures, which has been shown to lead to increased psychological distress among this age group (Elmer et al., 2020; Justo-Alonso et al., 2020).

This argument suggests that, compared to the young, older people face a higher health risk from Covid-19, while they also perceive lower costs from the preventive emergency policies passed to contain the virus. This asymmetry in the perceived costs and benefits of pandemic health policies should shape young and old people's evaluations of the political system. Of course, all people face a high level of uncertainty and a potential for anxious arousal in the face of the pandemic. It is also in the interest of the old and the young that the health care system does not collapse. Yet, older people have the strongest incentive to rally around 
political intuitions as they face a clear health risk, which requires effective collective action to be addressed. Younger people, on the contrary, face much more mixed signals. Health risks are less pronounced for the young, while the perceived social and psychological costs are arguably higher. It therefore is likely that the young are less enthusiastic about Covid-19 containment measures and feel less inclined to cling on to political institutions to provide strong and fast collective action. To be sure, we do not argue that the young do not show solidarity or that young people are actively opposed to the Covid-19 prevention policies by default. Instead, we merely suggest that the crisis effect of rallying around political institutions should be less pronounced among the young, as they have fewer incentives to attach themselves to political institutions as a lifebuoy.

H1: The rally effect in political trust is less pronounced among the young and stronger among older people.

\section{Economic risks}

Besides health risks, Covid-19 has led to severe negative economic consequences. Therefore, the distribution of (potential) economic risks across the population may influence support for the political system over the course of the crisis. We see two competing scenarios on how economic risks might shape the rally effect. On the one hand, the concentration of economic costs within certain groups might lead these people to withdraw support for emergency policies. The rally effect, therefore, should be absent in economically hard hit sectors or occupations. Of course, the immediate individual-level economic costs of the pandemic might not be that pronounced as it may take a while until negative effects reach individual households. However, it was rather clear from the beginning that the measures to fight the pandemic would entail high economic costs (Baekgaard et al., 2020). Moreover, research 
during the early stages of the crisis has documented a considerable increase in economic anxiety (Fetzer et al., 2020). Thus, individuals who have reason to expect financial hardship might be less enthusiastic about the emergency policies.

On the other hand, economic costs could still be too diffuse at the beginning of the pandemic. This might explain a rally effect across all economic groups. Indeed, recent evidence suggests that economic performance perceptions have lost explanatory power for political trust as the pandemic spread (Schraff, 2020). This is an interesting insight, as economic position (e.g., income) and perceptions of economic performance are central determinants of political trust (van der Meer \& Dekker, 2011; van der Meer \& Hakhverdian, 2017). Therefore, if an anxiety driven rally affect crowds out the usual cognitive evaluations, we should expect a strong increase in trust, especially among individuals with lower income, which are often shown to exhibit lower levels of trust (Gallego, 2016; Hetherington, 1998; Schraff, 2019). Thus, if economic evaluations indeed lose relevance during the pandemic, the less trusting economic groups should show the strongest rally effect.

H2a: The pandemic polarized people's political trust along the lines of economic groups.

$\mathrm{H} 2 \mathrm{~b}$ : The pandemic unifies people's political trust, leading low trusting economic groups to catch up in their trust levels.

\section{Partisan bias}

Finally, recent studies on the acceptance of public health measures during the pandemic put a lot of attention on partisanship. Yet, it is still contested whether partisan biases soften as the rally effect kicks in or whether partisanship amplifies polarization in political evaluations. On the one hand, part of the rally effect literature suggests that the pandemic has unified political camps (Anderson \& Hobolt, 2020; Merkley et al., 2020). If at all, heterogeneity in the 
rally effect on political trust has been found to be small (Esaiasson et al., 2020). On the other hand, behavioral evidence suggest that partisanship does shape individual compliance with public health measures. Studies from the highly polarized US context show that support for and compliance with Covid-19 policies varies across Republicans and Democrats (Allcott et al., 2020; Bhanot \& Hopkins, 2020; Goldstein \& Wiedemann, 2020; Grossman et al., 2020). It therefore is still unclear how partisanship shapes the rally effect.

Against this backdrop, we argue that partisanship matters with respect to the baseline level of trust with which people enter the health crisis. We propose that, in particular, supporters of populist parties can be expected to be more skeptical of the existing government and its policies (Hooghe et al., 2011; Rooduijn et al., 2016). In fact, anti-elitism is a defining feature of populism (Mudde, 2004; Rooduijn, 2013). It therefore seems highly relevant to investigate how populist supporters react to a pandemic shock that emboldens the role of elites, such as health experts, and provides unprecedented powers to the incumbent politicians.

In light of this, two scenarios are likely. First, if a rally effect works through general human reactions, such as anxious arousal, we should expect a softening of partisan divides as anxious arousal generates a strong perceived need for unified and effective governance. This should make the largest difference for populist voters who enter the pandemic from a more skeptical baseline. Partisans with relatively low levels of trust should show the strongest catch-up effect as Covid-19 incidence rise. We therefore would expect partisans to converge to a high level of political trust, mainly due to the rising trust among the more skeptical populist voters. Second, if the pandemic is strongly filtered by partisan biases, we should expect that the rally effect is mainly concentrated among government and mainstream supporters. If partisan biases prevail under crisis, skepticism and distrust among populist party supporters should hold them back and hinder a homogenous rally effect. 
H3a: Due to general anxious arousal, populist voters should show the strongest rally effect.

H3b: Due to strong partisan filters, populist voters should show the weakest rally effect.

\section{Data and Method}

To test our expectations, we rely on nationally representative individual-level panel data, fielded among approximately 1,800 respondents before and during the first Covid-19 wave in the Netherlands. Survey data for the pre-pandemic wave come from December 2019 and January 2020, establishing a clear pre-pandemic baseline. The data for the pandemic wave come from March 2020, the month in which the first Covid-19 wave hit the Netherlands. ${ }^{2}$ This panel data structure allows us to analyze individual-level change in political trust from the prepandemic to the pandemic wave. The data therefore establish a strong benchmark to assess the impact of the pandemic. Compared to existing survey experiments on the political consequences of the Covid-19 crisis, our panel data provide a more realistic setting by capturing individual-level changes in a real world context instead of an artificial experimental setting. Moreover, the panel structure improves the quality of inferences compared to existing studies that track single survey responses over the fieldwork period. ${ }^{3}$

We measure respondents' political trust in the national parliament by using a scale from 0 to 10, where low values indicate low levels of trust, while high values indicate high levels of

\footnotetext{
2 Data were collected within the LISS panel (Longitudinal Internet studies for the Social Sciences) from December 12, 2019 until January 28, 2020 for the pre-pandemic wave and from March 2, 2020 until March 31, 2020 for the pandemic wave. For a detailed overview of our final samples and the waves, see Table A1 to A3 in the appendix. For descriptive statistics see Table A4 to A6 in the appendix.

${ }^{3}$ The study by Esaiasson et al. (2020) does provide individual-level panel data, but their first wave lies already in the beginning of the pandemic. We believe our panel has an even clearer baseline. Moreover, while Esaiasson et al. (2020) provide evidence on Sweden, we contribute by providing evidence from the Netherlands, with a stronger focus on effect heterogeneity.
} 
trust. ${ }^{4}$ Furthermore, we capture the impact of the pandemic by merging the survey data with Covid-19 statistics reporting the number of daily-diagnosed cases. ${ }^{5}$ We merge Covid-19 incident numbers by day. These numbers are, by design, always zero in the first wave. In the second wave, fieldwork stretches over the whole month of March 2020 and we therefore match the Covid-19 numbers with the reported day of the interview. In all models specified below, we use the cumulative number of Covid-19 infections. Besides this, the data come with standard demographic variables including age, gender, education, income, and migration background. We classify age groups by younger (age $<=30$ ), middle (age $>30 \&$ age $<55$ ), and older (age $>=55$ ). For our investigation of economic groups, we rely on a measure of net household income and classify respondents into quartiles. We also use respondents' occupation and sector of employment as alternative operationalizations of economic groups. Finally, we capture partisanship with a pre-pandemic measure of people's vote choice in the last general election. We code individuals as populist supporters if they indicate a vote choice for the Forum for Democracy, the Party for Freedom, or the Socialist Party, following the coding of the PopuList (Rooduijn et al., 2019).

Our results are based on linear multilevel regression models with random effects at the individual-level. ${ }^{6}$ We prefer random effects models, as our moderator variables are largely stable over the two waves. Random effects models also allow us to include a set of temporally

\footnotetext{
${ }^{4}$ Note that the wording of the political trust question differs slightly between the pre-pandemic and pandemic wave. In the pre-pandemic questionnaire it reads: "Can you indicate, on a scale from 0 to 10, how much confidence you personally have in each of the following institutions?" [Dutch parliament] ( $0=$ "no confidence at all" - 10="full confidence"), while in the pandemic wave it reads: "For the following questions, please give me an answer on a scale from 0 to 10, where 0 means you have no confidence at all, and 10 means you have a lot of confidence. How much confidence do you personally have in...?" [The Dutch parliament] ( $0=$ "No confidence at all" - 10="A lot of confidence).

${ }^{5}$ Data were retrieved from CoronaWatchNL available at https://github.com/J535D165/CoronaWatchNL (accessed December 2020).

${ }^{6}$ As a robustness check, we also estimated fixed effects models (see Tables A7 and A8 in the appendix). The substantive findings remain the same.
} 
stable socio-demographic controls, such as education or migrant background. However, we provide two-way fixed effects models as robustness check in the Appendix. To detect possible effect heterogeneity in the rally effect, our models use interactions between the cumulative number of Covid-19 infections and indicators for respondents' age (H1), net household income, occupation, sector of employment ( $\mathrm{H} 2 \mathrm{a}$ and $\mathrm{H} 2 \mathrm{~b})$, and populist support ( $\mathrm{H} 3 \mathrm{a}$ and $\mathrm{H} 3 \mathrm{~b})$. For our economic groups hypotheses using net household income ( $\mathrm{H} 2 \mathrm{a}$ and $\mathrm{H} 2 \mathrm{~b}$ ), we restrict the estimation sample to respondents with direct risk exposure. Therefore, we omit respondents who derive their income outside the labor market, such as pensioners, pupils, or the unemployed. This leaves us with a sample of respondents who actually are at risk of losing out materially from the pandemic.

\section{Results}

Figure 1 presents the marginal effects of cumulative Covid-19 cases on political trust conditional on three different operationalizations of age shown in panel $A, B$ and $C$ respectively. The full regression output is provided in Table A9 in the appendix. All interactions are statistically significant at the five or one percent level. In line with our arguments, the rally effect seems to be absent among younger and strongly pronounced among older respondents. With growing numbers of Covid-19 cases, older respondents substantially increase their trust in the national parliament, while political trust for younger respondents remains stable. Based on this, there is strong evidence in favor of $\mathrm{H} 1$. Older individuals facing a considerably higher health risk from Covid-19 strongly rally around the flag once infection numbers surge. In contrast, younger individuals, who have lower health risks and are confronted with higher costs under the pandemic policies, change little in their political trust. These findings also hold 
under a fixed effects specification, as presented in Table A7 in the appendix. Overall, our panel data show that the rally effect substantially varies across age. Young respondents retain a moderately high level of trust, but are not mobilized over the course of the pandemic. The rally effect among the middle aged is positive and significant, yet only older respondents' political trust increases sharply in response to the Covid-19 crisis.

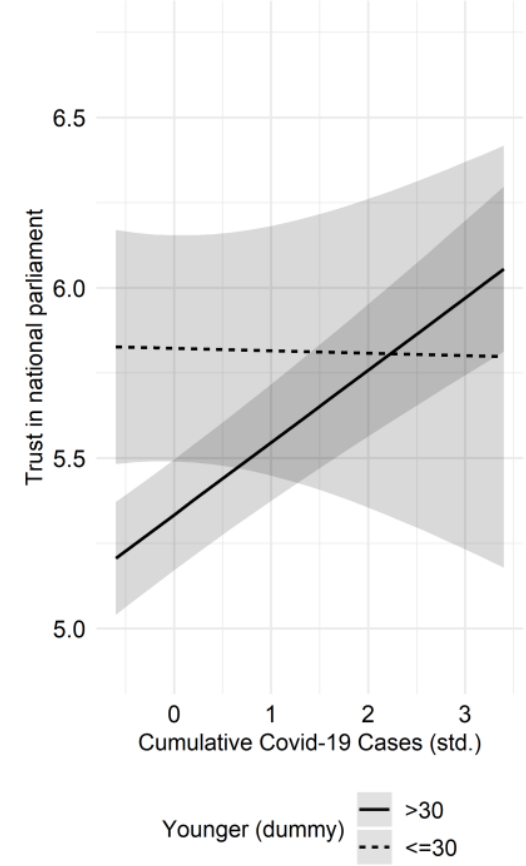

B

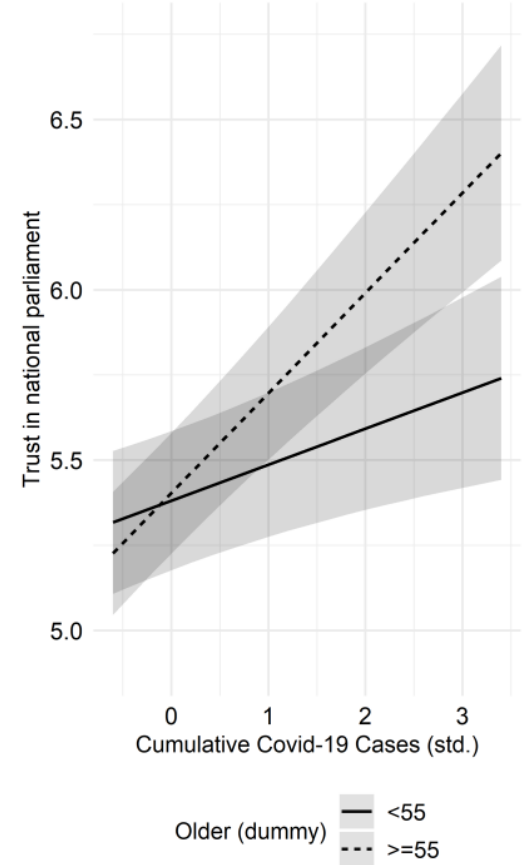

C

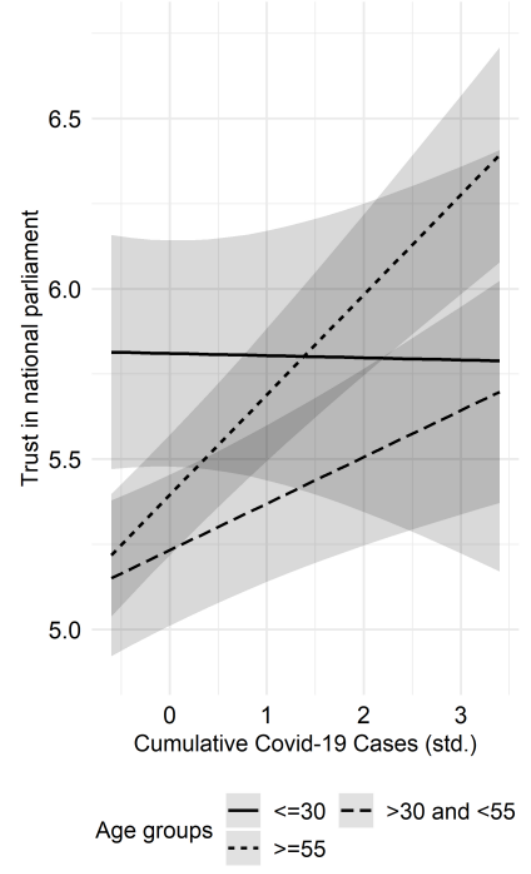

Figure 1. Marginal effects of cumulative Covid-19 cases on political trust conditional on different operationalizations of age. Marginal effects are displayed with 95\% confidence intervals. Full model results can be found in Table A9 in the appendix.

Figure 2 plots the marginal effects of cumulative Covid-19 infections on citizens' political trust conditional on respondents' household income (panel A) and populist voting behavior (panel B). Full model results are provided in Table A10 in the Appendix. All interactions are statistically significant at the one or five percent level. Looking at panel A of Figure 2, we see that political trust increases with rising numbers of Covid-19 infections regardless of a respondent's economic position. However, while richer as well as poorer individuals seem to rally around the flag, they appear to do so at significantly different rates. Individuals whose 
income falls within the first quartile exhibit a significantly higher leap in political trust. This effect is also robust to a fixed effects specification as shown in Table A8 in the Appendix. Clearly, these findings speak to the expectations of $\mathrm{H} 2 \mathrm{~b}$, lending credence to the argument that the Covid-19 pandemic unifies people's trust in politics as economic groups with generally lower levels of political trust catch up once the pandemic spreads. These results illustrate that the pandemic led to converging levels of trust, rather than further polarizing existing economic divides.

A

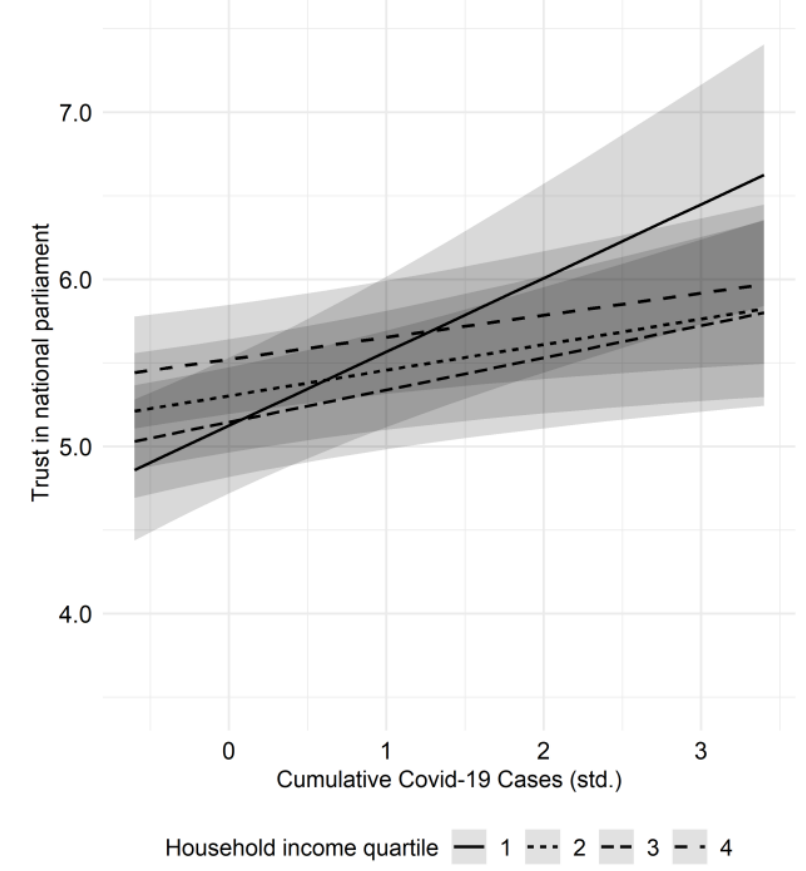

B

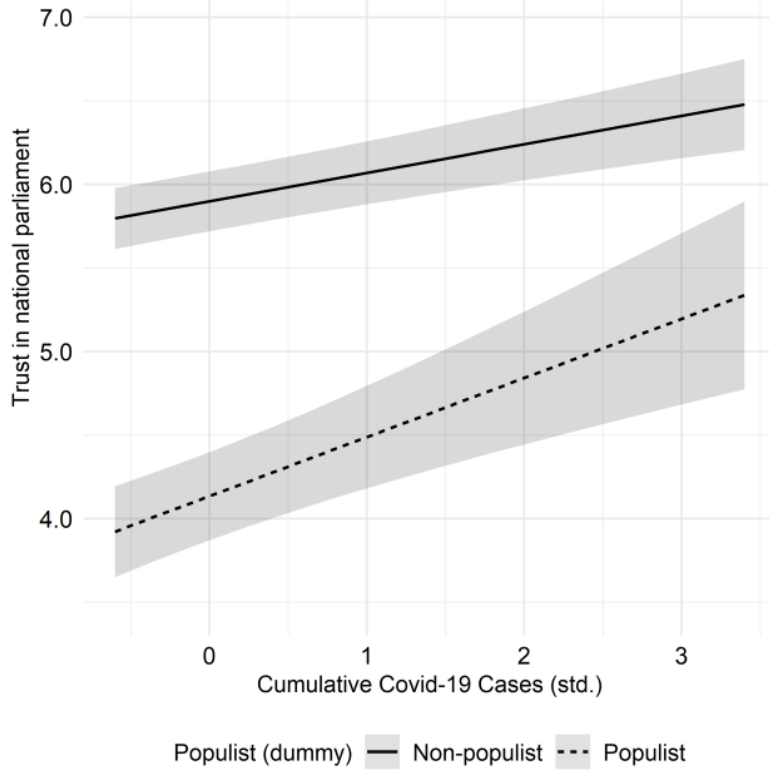

Figure 2. Marginal effects of cumulative Covid-19 cases on political trust conditional on household income quartiles (Panel A) and populist voting behavior (Panel B). Marginal effects are displayed with $95 \%$ confidence intervals. Full model results can be found in Table A10 in the appendix.

We also tested for effect heterogeneity across alternative operationalizations of economic groups. H2a suggests that occupations or economic sectors hard hit by the pandemic might not rally around the costly Covid-19 policies. To give this argument a fair shot, we tested for interactions between the cumulative Covid-19 numbers and occupational/sectoral groups. 
The results are presented in Tables A11 and A12 in the Appendix. Overall, we do not find systematic differences in the rally effect across occupational and sectoral groups. We do see that the rally effect is significantly less pronounced in the business services sector (including real estate) and is more pronounced among people employed in industrial production. Yet, we do not consider this to be strong evidence for systematic polarization across occupational or sectoral groups.

Panel B of Figure 2 engages with our expectations on populist supporters presented under $\mathrm{H} 3 \mathrm{a}$ and $\mathrm{H} 3 \mathrm{~b}$. The interaction effect implies a similar catch-up effect as we see in the income interaction. Although political trust levels of both populist and non-populist voters rise with the Coronavirus spreading, the rate at which populist voters rally around the flag is decidedly higher than that of non-populist voters, narrowing the trust gap between both groups substantially. Table A8 in the Appendix shows that this finding holds under a fixed-effects specification. Even though the interaction coefficient just misses the five percent significant level, the marginal effects suggest a very similar effect as depicted in panel B of Figure 2 . This finding supports $\mathrm{H} 3 \mathrm{a}$, as we show that political trust of populist and non-populist voters essentially converges at a higher level.

Overall, our findings suggest that standard economic and ideational divides in political trust cease to exist as the pandemic spreads, as skeptical citizens catch up with the rest of the population. This improves our understanding of the dynamics behind the rally effect. The increase in political trust is mainly a catch-up effect of people who are more distrusting during normal times. The underlying assumption of this catch-up effect is that individuals with low baseline trust levels are those showing the strongest rally effect. We can test this assumption by interacting the cumulative Covid-19 numbers with people's pre-pandemic trust levels. Figure 3 presents the marginal effects of this interaction and shows that those who rally 
strongest are people with the lowest levels of pre-pandemic trust. This effect heterogeneity is sizeable. On average, respondents increase their trust in politics by around 1 point on a 10point scale. In contrast, the rally effect ceases among respondents with a trust level of over 6.5 points.

This also shows that the catch-up dynamic is not driven by a ceiling effect. One might argue that the catch-up effect among low-trust respondents is due to the fact that high-trust respondents have already maxed out our political trust scale in the pre-pandemic period. Figure 3, however, shows that the effect already ceases way before the maximum value of 10 is reached. Note that we do not want to over-interpret the negative predicted values at the upper end of the x-axis of Figure 3 , as the number of observations gets very low towards the end of the scale.

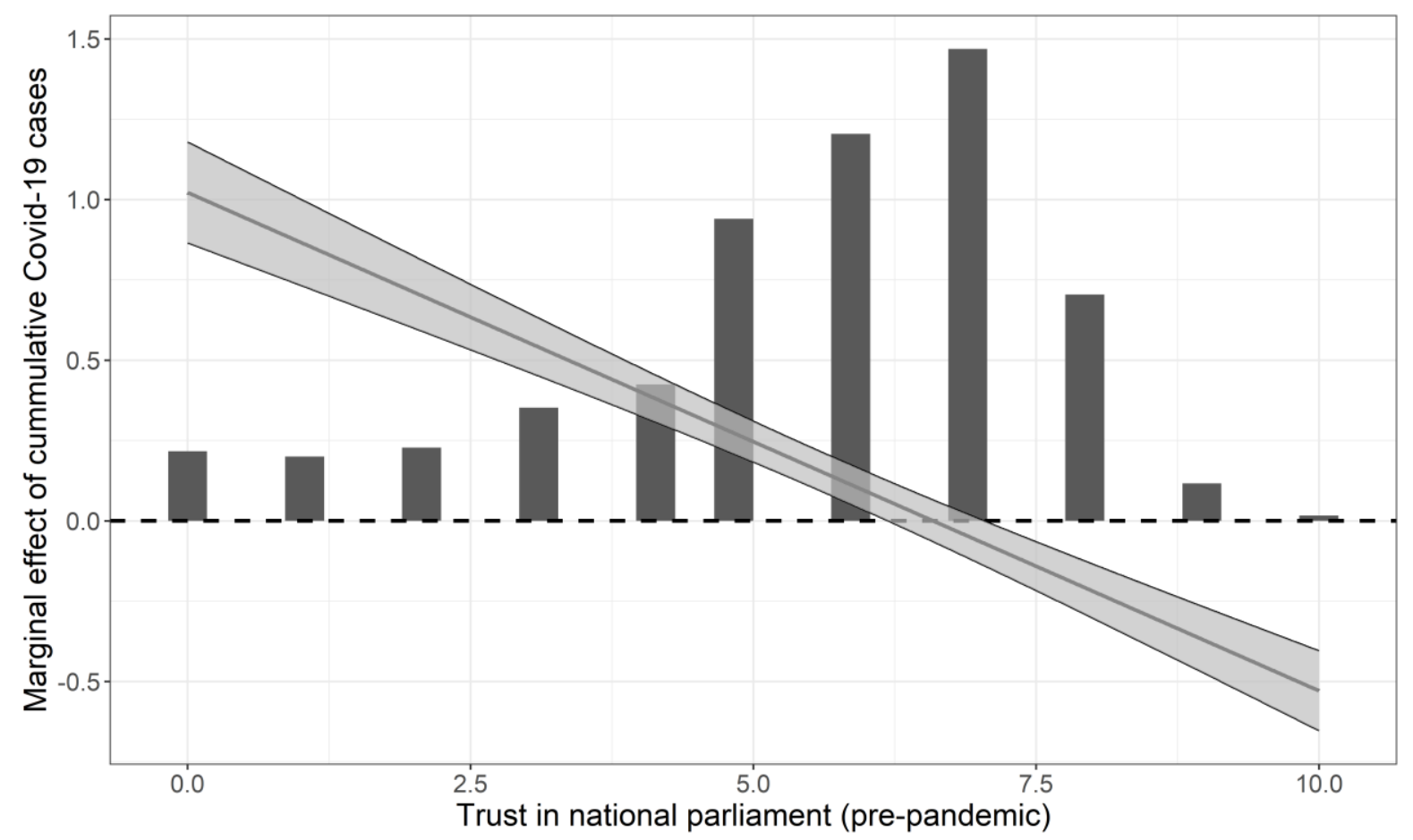

Figure 3. Marginal effects of cumulative Covid-19 cases on political trust conditional on prepandemic trust levels. Marginal effects are displayed with 95\% confidence intervals. Full model results can be found in Table A13 in the Appendix. 
In summary, our analysis shows that the pandemic rally effect on political trust varies substantially across individuals. Whereas younger respondents' political trust remains unaffected by the crisis, older individuals strongly increase their trust in parliament as the pandemic spreads. We argue that this is due to an asymmetric distribution of costs and risks. On the one hand, older generations, who are confronted with higher health risks from Covid19 , strongly rally around political institutions to back preventive emergency policies passed to contain the virus. On the other hand, the rally effect is absent among younger generations, since their risk of a severe Covid-19 infection is lower, while their perceived costs under pandemic policies are arguably higher. In addition to that, we find that individuals from lower income brackets and populist voters, commonly characterized by low levels of trust, catch up with the more trusting parts of the population. This refines our understanding of the rally effect in an important way. The rally effect is largely driven by people who are more distrusting of political institutions under normal times, giving up their skeptical stance in times of collective societal threat.

\section{Conclusion}

A successful response of democratic societies to the Covid-19 pandemic critically hinges on citizens' trust in politics. Without a basic level of confidence in the political system, consent and compliance with policy measures intended to contain the virus will be put in jeopardy. In response to this concern, early research on the pandemic has documented a rally around the flag effect, diagnosing exceptionally high levels of political trust during the first wave of the crisis (Devine et al., 2020). Yet, although this effect has been established across various country-contexts, we currently lack insights on the people who drive this effect. This is 
consequential, as it constrains our knowledge about the kind of persons who might or might not be willing to comply with Covid-19 policies.

In this paper, we argue that individual responses to the pandemic rest on the potential health risks and economic repercussions people face. First, we suggest that risks and costs are asymmetrically distributed across age groups. Older respondents have reason to worry about a severe Covid-19 infection and therefore rally around political institutions for shelter. Younger respondents face lower health risks, but higher costs from Covid-19 policies, and therefore do not rally around political institutions as the pandemic hits. Second, we argue that generally more distrusting people catching up to the rest of the population might drive the rally effect. We suggest that such a dynamic could be visible among low-income earners and populist party supporters. Alternatively, we propose that potential economic repercussions from the pandemic might polarize economic groups.

We provide an analysis of the effect heterogeneity in the rally effect, using individual-level panel data on a sample of around 1,800 respondents covering the time before and during the first Covid-19 wave in the Netherlands. In contrast to existing studies, this data allows us to analyze individual-level changes in citizens' trust from the pre-pandemic to the pandemic context. We show that the rally effect is strong among the old, while it is absent among the young. Moreover, we identify a catch-up effect, whereby individuals from conventionally low trusting groups exhibit the highest boost in political trust during the course of the crisis. We find that distrusting individuals, such as low-income earners and populist party supporters, drive the rally effect in political trust. In contrast, we do not find systematic evidence for a polarization of political trust across economic groups or partisans. 
These findings are important in two primary ways. First, our results shed light on the dynamics of the rally effect, allowing for the conclusion that people surrender their skepticism towards political institutions in view of a collective social threat. This provides for a silver lining during a period of uncertainty and upheaval. After all, if people from opposite ends of society manage to come together to address an urgent problem by means of collective action, a determined and ultimately successful response to handle the crisis becomes more likely.

Second, on a less optimistic note, we find that the young have not increased their political trust during the pandemic. This suggests that political trust among the young remains as polarized as in normal times, as our results provide no indication of convergence along ideological or economic divides. This finding underlines the difficult situation of the younger generation during the pandemic. A remaining potential for polarization among the young hints at cracks within the societal consensus that might become more problematic as the pandemic drags on. Our sample is not powerful enough to provide detailed analysis of the rally effect within the group of young respondents. However, our findings suggest that this would be highly relevant endeavor for future research.

Finally, we want to highlight some important limitations of our study. Our panel data is currently not suitable to study long-term effects of the pandemic. How long the rally effect persists, therefore, remains an open question for future research. Moreover, the cost of using high quality panel data is the limited external validity. The rally effect and the relevance of moderating factors most likely vary across countries. While our findings demonstrate the rather general point that people's initial levels of trust at the start of the pandemic matters, the societal groups falling into the category of low trusting individuals can change over societies. However, by focusing on low-income individuals and populist supporters, we have worked with social groups that travel rather well across contexts. Furthermore, comparative 
research on the pandemic suggests that the public opinion dynamics in the Netherlands fit well into the overall picture across Europe (Bol et al., 2020). Therefore, we are confident that our findings carry some important implications for other country contexts and invite more studies of effect heterogeneity across different societal settings. 


\section{References}

Allcott, H., Boxell, L., Conway, J., Gentzkow, M., Thaler, M. \& Yang, D. (2020). Polarization and public health: Partisan differences in social distancing during the coronavirus pandemic. Journal of Public Economics 191: 104254. Retrieved from https://doi.org/10.1016/j.jpubeco.2020.104254

Amat, F., Arenas, A., Falcó-Gimeno, A. \& Muñoz, J. (2020). Pandemics meet democracy: Experimental evidence from the COVID-19 crisis in Spain [working paper, April 5 2020].

Anderson, C.J. \& Hobolt, S.B. (2020). No partisan divide in willingness to wear masks in the UK. LSE COVID-19 blog. Retrieved from https://blogs.Ise.ac.uk/covid19/2020/11/18/nopartisan-divide-in-willingness-to-wear-masks-in-the-uk/

Baekgaard, M., Christensen, J., Madsen, J.K. \& Mikkelsen, K.S. (2020). Rallying around the flag in times of COVID-19: Societal lockdown and trust in democratic institutions. Journal of Behavioral Public Administration 3(2): 1-28.

Bechtel, M.M. \& Hainmueller, J. (2011). How Lasting Is Voter Gratitude? An Analysis of the Short- and Long-Term Electoral Returns to Beneficial Policy. American Journal of Political Science 55(4): 852-868.

Bhanot, S.P. \& Hopkins, D.J. (2020). Partisan polarization and resistance to elite messages: Results from survey experiments on social distancing. Journal of Behavioral Public Administration 3(2).

Bol, D., Blais, A., Giani, M. \& Loewen, P.J. (2020). The effect of COVID-19 lockdowns on political support: Some good news for democracy? European Journal of Political Research 1-13.

Devine, D., Gaskell, J., Jennings, W. \& Stoker, G. (2020). Trust and the Coronavirus Pandemic: 
What are the Consequences of and for Trust? An Early Review of the Literature. Political Studies Review 1-12.

Dryhurst, S., Schneider, C.R., Kerr, J., Freeman, A.L.J., Recchia, G., van der Bles, A.M., ... van der Linden, S. (2020). Risk perceptions of COVID-19 around the world. Journal of Risk Research 0(0): 1-13. Retrieved from https://doi.org/10.1080/13669877.2020.1758193

Easton, D. (1975). A re-assessment of the concept of political support. British Journal of $\begin{array}{lllll}\text { Political Science } & \text { 5(4): } & \text { 435-457. } & \text { Retrieved }\end{array}$ http://journals.cambridge.org/abstract_S0007123400008309

Elmer, T., Mepham, K. \& Stadtfeld, C. (2020). Students under lockdown: Comparisons of students' social networks and mental health before and during the COVID-19 crisis in Switzerland. PLOS ONE 15(7 July): 1-22. Retrieved from http://dx.doi.org/10.1371/journal.pone.0236337

Esaiasson, P., Sohlberg, J., Ghersetti, M. \& Johansson, B. (2020). How the coronavirus crisis affects citizen trust in government institutions and in unknown others - Evidence from "the Swedish Experiment". European Journal of Political Research.

Fetzer, T., Hensel, L., Hermle, J. \& Roth, C. (2020). Coronavirus perceptions and economic anxiety. Review of Economics and Statistics.

Gallego, A. (2016). Inequality and the erosion of trust among the poor: experimental evidence. Socio-Economic Review 14(3): 446-460. Retrieved from http://ser.oxfordjournals.org/lookup/doi/10.1093/ser/mww010

Goldstein, D. \& Wiedemann, J. (2020). Who Do You Trust? The Consequences of Partisanship and Trust in Government for Public Responsiveness to COVID-19. SSRN Electronic Journal. 
Grossman, G., Kim, S., Rexer, J.M. \& Thirumurthy, H. (2020). Political partisanship influences behavioral responses to governors' recommendations for COVID-19 prevention in the United States. Proceedings of the National Academy of Sciences of the United States of America 117(39): 24144-24153.

Hardin, R. (2000). Do we want trust in government? In M. E. Warren (ed.), Democracy and Trust. Cambridge: Cambridge University Press.

Hetherington, M. (1998). The political relevance of political trust. American Political Science Review 92(4): 791-808. Retrieved from http://www.jstor.org/stable/2586304

Hooghe, M., Marien, S. \& Pauwels, T. (2011). Where Do Distrusting Voters Turn if There is No Viable Exit or Voice Option? The Impact of Political Trust on Electoral Behaviour in the Belgian Regional Elections of June 2009. Government and Opposition 46(2): 245-273.

Justo-Alonso, A., García-Dantas, A., González-Vázquez, A.l., Sánchez-Martín, M. \& del RíoCasanova, L. (2020). How did different generations cope with the COVID-19 pandemic? Early stages of the pandemic in Spain. Psicothema 32(4): 490-500.

Leininger, A. \& Schaub, M. (2020). Voting at the dawn of a global pandemic (April).

Levi, M. \& Stoker, L. (2000). Political trust and trustworthiness. Annual Review of Political $\begin{array}{lllll}\text { Science } & \text { 3: } & \text { 475-507. } & \text { Retrieved }\end{array}$ http://www.annualreviews.org/doi/abs/10.1146/annurev.polisci.3.1.475

Marien, S. \& Hooghe, M. (2011). Does political trust matter? An empirical investigation into the relation between political trust and support for law compliance. European Journal of Political Research 50(2): 267-291.

Marien, S. \& Werner, H. (2019). Fair treatment, fair play? The relationship between fair 
treatment perceptions, political trust and compliant and cooperative attitudes crossnationally. European Journal of Political Research 58(1): 72-95.

Merkley, E., Bridgman, A., Loewen, P.J., Owen, T., Ruths, D. \& Zhilin, O. (2020). A Rare Moment of Cross-Partisan Consensus: Elite and Public Response to the COVID-19 Pandemic in Canada. Canadian Journal of Political Science (May): 1-8.

Mudde, C. (2004). The Populist Zeitgeist. Government and Opposition 39(4): 541-563.

Rooduijn, M. (2013). The nucleus of populism: In search of the lowest common denominator. Government and Opposition 49(4): 572-598.

Rooduijn, M., Van der Brug, W. \& de Lange, S.L. (2016). Expressing or fuelling discontent? The relationship between populist voting and political discontent. Electoral Studies 43: 3240. Retrieved from http://dx.doi.org/10.1016/j.electstud.2016.04.006

Rooduijn, M., Van Kessel, S., Froio, C., Pirro, A., De Lange, S., Halikiopoulou, D., Lewis, P., ... Taggart, P. (2019). The PopuList: An Overview of Populist, Far Right, Far Left and Eurosceptic Parties in Europe. Retrieved from www.popu-list.org.

Schraff, D. (2019). Politically Alienated Through Low-Wage Work? Evidence from Panel Data. Swiss Political Science Review 25(1): 19-39. Retrieved from http://doi.wiley.com/10.1111/spsr.12342

Schraff, D. (2020). Political trust during the Covid-19 pandemic: Rally around the flag or lockdown effects? European Journal of Political Research. Retrieved from https://osf.io/preprints/socarxiv/pu47c/

Tabri, N., Hollingshead, S.J. \& Wohl, M.J.A. (2020). Framing COVID-19 as an Existential Threat Predicts Anxious Arousal and Prejudice towards Chinese People. PsyArXiv. 
van der Meer, T. \& Dekker, P. (2011). Trusting Citizens? A Multilevel Study into Objective and Subjective Determinants of Political Trust. In S. Zmerli \& M. Hooghe (eds.), Political Trust. Why Context Matters. Colchester: ECPR Press.

van der Meer, T. \& Hakhverdian, A. (2017). Political trust as the evaluation of process and performance: A Cross-national study of 42 European countries. Political Studies 65(1): 81-102.

Zheng, Z., Peng, F., Xu, B., Zhao, J., Liu, H., Peng, J., ... Tang, W. (2020). Risk factors of critical \& mortal COVID-19 cases: A systematic literature review and meta-analysis. Journal of Infection 81(2): e16-e25. 


\section{Appendix}

Table A1. Sample selection process for testing H1.

\begin{tabular}{|c|c|c|c|}
\hline Step & Reason missing & $\begin{array}{l}\text { N level-1: } \\
\text { Individuals } \\
\text { (dropped) }\end{array}$ & $\begin{array}{l}\text { N level-2: } \\
\text { LISS Waves }\end{array}$ \\
\hline Starting sample & & 1,832 & 1 \\
\hline $\begin{array}{l}\text { 1. Merge LISS pandemic } \\
\text { wave with LISS pre- } \\
\text { pandemic wave }\end{array}$ & $\begin{array}{l}\text { Present in pandemic wave, } \\
\text { but missing in pre- } \\
\text { pandemic wave }\end{array}$ & $1,829(3)$ & 2 \\
\hline $\begin{array}{l}\text { 2. Reshape data from wide } \\
\text { to long format and add } \\
\text { further background data }\end{array}$ & $\begin{array}{l}\text { Present in merged LISS } \\
\text { data, but missing in LISS } \\
\text { background data }\end{array}$ & $1,826(3)$ & 2 \\
\hline 3. Add national-level & & 1,826 & 2 \\
\hline COVID-19 Data & & & \\
\hline $\begin{array}{l}\text { 4. Drop observations with } \\
\text { missing datum in pre- } \\
\text { pandemic wave and } \\
\text { balance panel }\end{array}$ & & $1,676(150)$ & 2 \\
\hline $\begin{array}{l}\text { 5. Drop observations of } \\
\text { missing variables used in } \\
\text { models testing } \mathrm{H} 1 \text { and } \\
\text { balance panel }\end{array}$ & & $1,415(261)$ & 2 \\
\hline
\end{tabular}

Table A2. Sample selection process for testing $\mathrm{H} 2 \mathrm{a}$ and $\mathrm{H} 2 \mathrm{~b}$.

\begin{tabular}{|c|c|c|c|}
\hline Step & Reason missing & $\begin{array}{l}\text { N level-1: } \\
\text { Individuals } \\
\text { (dropped) }\end{array}$ & $\begin{array}{l}\text { N level-2: } \\
\text { LISS Waves }\end{array}$ \\
\hline Starting sample & & 1,832 & 1 \\
\hline $\begin{array}{l}\text { 1. Merge LISS pandemic } \\
\text { wave with LISS pre- } \\
\text { pandemic wave }\end{array}$ & $\begin{array}{l}\text { Present in pandemic wave, } \\
\text { but missing in pre- } \\
\text { pandemic wave }\end{array}$ & $1,829(3)$ & 2 \\
\hline $\begin{array}{l}\text { 2. Reshape data from wide } \\
\text { to long format and add } \\
\text { further background data }\end{array}$ & $\begin{array}{l}\text { Present in merged LISS } \\
\text { data, but missing in LISS } \\
\text { background data }\end{array}$ & $1,826(3)$ & 2 \\
\hline $\begin{array}{l}\text { 3. Add national-level } \\
\text { COVID-19 Data }\end{array}$ & & 1,826 & 2 \\
\hline $\begin{array}{l}\text { 4. Drop observations with } \\
\text { missing datum in pre- } \\
\text { pandemic wave and } \\
\text { balance panel }\end{array}$ & & $1,676(150)$ & 2 \\
\hline $\begin{array}{l}\text { 5. Restrict sample to } \\
\text { observations with income } \\
\text { from inside the labor } \\
\text { market. Drop observations } \\
\text { with missing values on } \\
\text { variables used in models } \\
\text { testing } \mathrm{H} 2 \mathrm{a} \text { and } \mathrm{H} 2 \mathrm{~b} \text { and } \\
\text { balance panel }\end{array}$ & & $638(1038)$ & 2 \\
\hline
\end{tabular}


Table A3. Sample selection process for testing $\mathrm{H} 3 \mathrm{a}$ and $\mathrm{H} 3 \mathrm{~b}$.

\begin{tabular}{|c|c|c|c|}
\hline Step & Reason missing & $\begin{array}{l}\text { N level-1: } \\
\text { Individuals } \\
\text { (dropped) }\end{array}$ & $\begin{array}{l}\text { N level-2: } \\
\text { LISS Waves }\end{array}$ \\
\hline Starting sample & & 1,832 & 1 \\
\hline $\begin{array}{l}\text { 1. Merge LISS pandemic } \\
\text { wave with LISS pre- } \\
\text { pandemic wave }\end{array}$ & $\begin{array}{l}\text { Present in pandemic wave, } \\
\text { but missing in pre- } \\
\text { pandemic wave }\end{array}$ & $1,829(3)$ & 2 \\
\hline $\begin{array}{l}\text { 2. Reshape data from wide } \\
\text { to long format and add } \\
\text { further background data }\end{array}$ & $\begin{array}{l}\text { Present in merged LISS } \\
\text { data, but missing in LISS } \\
\text { background data }\end{array}$ & $1,826(3)$ & 2 \\
\hline $\begin{array}{l}\text { 3. Add national-level } \\
\text { COVID-19 Data }\end{array}$ & & 1,826 & 2 \\
\hline $\begin{array}{l}\text { 4. Drop observations with } \\
\text { missing datum in pre- } \\
\text { pandemic wave and } \\
\text { balance panel }\end{array}$ & & $1,676(150)$ & 2 \\
\hline $\begin{array}{l}\text { 5. Drop observations of } \\
\text { missing variables used in } \\
\text { models testing } \mathrm{H} 3 \mathrm{a} \text { and } \\
\mathrm{H} 3 \mathrm{~b} \text { and balance panel }\end{array}$ & $\begin{array}{l}\text { Substantial number of } \\
\text { missing values in the party } \\
\text { preference variable }\end{array}$ & $1,103(573)$ & 2 \\
\hline
\end{tabular}

Table A4. Descriptive statistics for sample testing H1.

\begin{tabular}{lrcccccc}
\hline Statistic & $\mathrm{N}$ & Mean & St. Dev. & Min & Pctl(25) & Pctl(75) & Max \\
\hline Trust in national parliament & 2,830 & 5.628 & 2.101 & 0 & 5 & 7 & 10 \\
Cumulative Covid-19 Cases (Std.) & 2,830 & -0.018 & 0.979 & -0.465 & -0.465 & -0.212 & 3.500 \\
Net household income (Std.) & 2,830 & 0.001 & 0.984 & -1.717 & -0.658 & 0.503 & 12.369 \\
Age (Std.) & 2,830 & 0.067 & 0.970 & -2.248 & -0.611 & 0.801 & 2.157 \\
Older & 2,830 & 0.598 & 0.490 & 0 & 0 & 1 & 1 \\
Younger & 2,830 & 0.097 & 0.296 & 0 & 0 & 0 & 1 \\
High education & 2,830 & 0.405 & 0.491 & 0 & 0 & 1 & 1 \\
Gender & 2,830 & 0.470 & 0.499 & 0 & 0 & 1 & 1 \\
Migrant background & 2,830 & 0.155 & 0.362 & 0 & 0 & 0 & 1 \\
\hline
\end{tabular}

Table A5. Descriptive statistics for sample testing $\mathrm{H} 2 \mathrm{a}$ and $\mathrm{H} 2 \mathrm{~b}$.

\begin{tabular}{lrcccccc}
\hline Statistic & $\mathrm{N}$ & Mean & St. Dev. & Min & Pctl(25) & Pctl(75) & Max \\
\hline Trust in national parliament & 1,276 & 5.765 & 2.057 & 0 & 5 & 7 & 10 \\
Cumulative Covid-19 Cases (Std.) & 1,276 & 0.079 & 1.095 & -0.465 & -0.465 & -0.163 & 3.500 \\
Age (Std.) & 1,276 & -0.464 & 0.672 & -1.910 & -1.006 & 0.067 & 1.705 \\
High education & 1,276 & 0.504 & 0.500 & 0 & 0 & 1 & 1 \\
Gender & 1,276 & 0.505 & 0.500 & 0 & 0 & 1 & 1 \\
Migrant background & 1,276 & 0.165 & 0.371 & 0 & 0 & 0 & 1 \\
\hline
\end{tabular}


Table A6. Descriptive statistics for sample testing $\mathrm{H} 3 \mathrm{a}$ and $\mathrm{H} 3 \mathrm{~b}$.

\begin{tabular}{lccccccc}
\hline Statistic & $\mathrm{N}$ & Mean & St. Dev. & Min & Pctl(25) & Pctl(75) & Max \\
\hline Trust in national parliament & 2,206 & 5.812 & 2.024 & 0 & 5 & 7 & 10 \\
Cumulative Covid-19 Cases (Std.) & 2,206 & -0.042 & 0.945 & -0.465 & -0.465 & -0.272 & 3.500 \\
Net household income (Std.) & 2,206 & 0.052 & 1.000 & -1.717 & -0.590 & 0.537 & 12.369 \\
Age (Std.) & 2,206 & 0.182 & 0.921 & -2.023 & -0.441 & 0.858 & 2.100 \\
Populist & 2,206 & 0.188 & 0.391 & 0 & 0 & 0 & 1 \\
High education & 2,206 & 0.441 & 0.497 & 0 & 0 & 1 & 1 \\
Gender & 2,206 & 0.489 & 0.500 & 0 & 0 & 1 & 1 \\
Migrant background & 2,206 & 0.121 & 0.327 & 0 & 0 & 0 & 1 \\
\hline
\end{tabular}

Table A7. Two-way fixed effect models with age interactions.

\begin{tabular}{|c|c|c|c|}
\hline & $(1)$ & $(2)$ & $(3)$ \\
\hline \multirow[t]{2}{*}{ Cumulative Covid-19 Cases (Std.) } & $0.159^{* * *}$ & 0.059 & -0.069 \\
\hline & $(0.034)$ & $(0.040)$ & $(0.084)$ \\
\hline \multirow[t]{2}{*}{ Younger (b.>30) } & 0.362 & & \\
\hline & $(0.684)$ & & \\
\hline \multirow[t]{2}{*}{ Older (b.<55) } & & -0.113 & \\
\hline & & $(0.881)$ & \\
\hline \multicolumn{4}{|l|}{ Age categories $(b .<=30)$} \\
\hline \multirow[t]{2}{*}{$>=55$} & & & -0.451 \\
\hline & & & (1.116) \\
\hline \multirow[t]{2}{*}{$>30$ and $<55$} & & & -0.322 \\
\hline & & & (0.683) \\
\hline \multirow[t]{2}{*}{ Net household income (Std.) } & -0.112 & -0.108 & -0.114 \\
\hline & $(0.089)$ & $(0.088)$ & (0.088) \\
\hline \multirow[t]{2}{*}{ Cumulative Covid-19 Cases (Std.)*Younger } & $-0.232^{* * *}$ & & \\
\hline & $(0.087)$ & & \\
\hline \multirow[t]{2}{*}{ Cumulative Covid-19 Cases (Std.)*Older } & & $0.181^{* * *}$ & \\
\hline & & $(0.054)$ & \\
\hline \multirow{2}{*}{\multicolumn{4}{|c|}{$\begin{array}{l}\text { Cumulative Covid-19 Cases (Std.) } \\
\text { *Age categories }\end{array}$}} \\
\hline & & & \\
\hline \multirow[t]{2}{*}{$>=55$} & & & $0.309^{* * *}$ \\
\hline & & & $(0.091)$ \\
\hline \multirow[t]{2}{*}{$>30$ and $<55$} & & & $0.158^{*}$ \\
\hline & & & $(0.091)$ \\
\hline Observations & 2,830 & 2,830 & 2,830 \\
\hline Groups & 1,415 & 1,415 & 1,415 \\
\hline $\mathrm{R}^{2}$ & 0.018 & 0.020 & 0.023 \\
\hline
\end{tabular}


Table A8. Two-way fixed effect models with income and populist voting behavior interactions.

\begin{tabular}{|c|c|c|}
\hline & $(1)$ & $(2)$ \\
\hline \multirow[t]{2}{*}{ Cumulative Covid-19 Cases (Std.) } & $0.392^{* * *}$ & $0.125^{* * *}$ \\
\hline & $(0.110)$ & $(0.038)$ \\
\hline \multicolumn{3}{|l|}{ Household income quartiles (b.1st) } \\
\hline \multirow[t]{2}{*}{ 2nd Household income quartile } & 0.244 & \\
\hline & $(0.441)$ & \\
\hline \multirow[t]{2}{*}{ 3rd Household income quartile } & -0.316 & \\
\hline & $(0.551)$ & \\
\hline \multirow[t]{2}{*}{ 4th Household income quartile } & -0.069 & \\
\hline & $(0.591)$ & \\
\hline \multicolumn{3}{|l|}{$\begin{array}{l}\text { Cumulative Covid-19 Cases (Std.) } \\
{ }^{*} \text { Household income quartiles }\end{array}$} \\
\hline \multirow[t]{2}{*}{ 2nd Household income quartile } & $-0.281^{* *}$ & \\
\hline & $(0.124)$ & \\
\hline \multirow[t]{2}{*}{ 3rd Household income quartile } & $-0.228^{*}$ & \\
\hline & $(0.127)$ & \\
\hline \multirow[t]{2}{*}{ 4th Household income quartile } & $-0.323^{* * *}$ & \\
\hline & $(0.120)$ & \\
\hline \multirow[t]{2}{*}{ Net household income (Std.) } & & -0.128 \\
\hline & & $(0.086)$ \\
\hline \multirow[t]{2}{*}{$\begin{array}{l}\text { Cumulative Covid-19 Cases (Std.) } \\
\text { *Populist }\end{array}$} & & $0.162^{*}$ \\
\hline & & $(0.083)$ \\
\hline Observations & 1,276 & 2,206 \\
\hline Groups & 638 & 1,103 \\
\hline $\mathrm{R}^{2}$ & 0.030 & 0.020 \\
\hline Note: & $\mathrm{p}<0.1 ;{ }^{* *} \mathrm{p}<$ & ${ }^{* * * *} p<0$. \\
\hline
\end{tabular}


Table A9. Random effect models with age interactions.

\begin{tabular}{|c|c|c|c|}
\hline & $(1)$ & $(2)$ & (3) \\
\hline \multirow[t]{2}{*}{ Cumulative Covid-19 Cases (Std.) } & $0.212^{* * *}$ & $0.106^{* * *}$ & -0.006 \\
\hline & $(0.027)$ & $(0.034)$ & $(0.078)$ \\
\hline \multirow[t]{2}{*}{ Younger (b.>30) } & $0.489^{* * *}$ & & \\
\hline & $(0.165)$ & & \\
\hline \multirow[t]{2}{*}{ Older (b.<55) } & & 0.022 & \\
\hline & & $(0.103)$ & \\
\hline \multicolumn{4}{|l|}{ Age categories $(b .<=30)$} \\
\hline \multirow[t]{2}{*}{$>=55$} & & & $-0.416^{* *}$ \\
\hline & & & $(0.171)$ \\
\hline \multirow[t]{2}{*}{$>30$ and $<55$} & & & $-0.578^{* * *}$ \\
\hline & & & (0.179) \\
\hline \multirow[t]{2}{*}{ High education (b. low education) } & $0.859^{* * *}$ & $0.880^{* * *}$ & $0.868^{* * *}$ \\
\hline & $(0.104)$ & $(0.105)$ & $(0.104)$ \\
\hline \multirow[t]{2}{*}{ Net household income (Std.) } & $0.148^{* * *}$ & $0.139^{* * *}$ & $0.152^{* * *}$ \\
\hline & $(0.046)$ & $(0.046)$ & $(0.046)$ \\
\hline \multirow[t]{2}{*}{ Male (b.Female) } & -0.138 & $-0.169^{*}$ & -0.145 \\
\hline & $(0.100)$ & $(0.101)$ & $(0.100)$ \\
\hline \multirow[t]{2}{*}{ Migrant background (b. Dutch background) } & -0.204 & -0.186 & -0.182 \\
\hline & $(0.138)$ & $(0.139)$ & $(0.139)$ \\
\hline \multirow[t]{2}{*}{ Cumulative Covid-19 Cases (Std.)*Younger } & $-0.219^{* * *}$ & & \\
\hline & $(0.083)$ & & \\
\hline \multirow[t]{2}{*}{ Cumulative Covid-19 Cases (Std.)*Older } & & $0.188^{* * *}$ & \\
\hline & & $(0.051)$ & \\
\hline \multirow{2}{*}{\multicolumn{4}{|c|}{$\begin{array}{l}\text { Cumulative Covid-19 Cases (Std.) } \\
\text { *Age categories }\end{array}$}} \\
\hline & & & \\
\hline \multirow[t]{2}{*}{$>=55$} & & & $0.300^{* * *}$ \\
\hline & & & $(0.087)$ \\
\hline \multirow[t]{2}{*}{$>30$ and $<55$} & & & $0.143^{*}$ \\
\hline & & & $(0.087)$ \\
\hline \multirow[t]{2}{*}{ Constant } & $5.333^{* * *}$ & $5.380^{* * *}$ & $5.810^{* * *}$ \\
\hline & $(0.083)$ & $(0.104)$ & (0.169) \\
\hline Between individual variance & 2.910 & 2.932 & 2.907 \\
\hline Within individual variance & 1.173 & 1.168 & 1.168 \\
\hline Observations & 2,830 & 2,830 & 2,830 \\
\hline Groups & 1,415 & 1,415 & 1,415 \\
\hline Note: & ${ }^{*} p<0.1$ & ${ }^{* *} p<0.05$ & ${ }^{* * *} p<0.01$ \\
\hline
\end{tabular}


Table A10. Random effect models with income and populist voting behavior interactions.

\begin{tabular}{|c|c|c|}
\hline & (1) & $(2)$ \\
\hline \multirow[t]{2}{*}{ Cumulative Covid-19 Cases (Std.) } & $0.441^{* * *}$ & $0.170^{* * *}$ \\
\hline & $(0.101)$ & $(0.031)$ \\
\hline \multicolumn{3}{|l|}{ Household income quartiles (b.1st) } \\
\hline \multirow[t]{2}{*}{ 2nd Household income quartile } & 0.178 & \\
\hline & $(0.223)$ & \\
\hline \multirow[t]{2}{*}{ 3rd Household income quartile } & 0.021 & \\
\hline & $(0.228)$ & \\
\hline \multirow[t]{2}{*}{ 4th Household income quartile } & $0.397^{*}$ & \\
\hline & $(0.225)$ & \\
\hline \multirow[t]{2}{*}{ Populist (b.Non-populist) } & & $-1.764^{* * *}$ \\
\hline & & $(0.135)$ \\
\hline \multirow[t]{2}{*}{ High education (b. low education) } & $1.089^{* * *}$ & $0.529^{* * *}$ \\
\hline & $(0.150)$ & $(0.109)$ \\
\hline \multirow[t]{2}{*}{ Net household income (Std.) } & & 0.053 \\
\hline & & $(0.047)$ \\
\hline \multirow[t]{2}{*}{ Age (Std.) } & 0.044 & -0.005 \\
\hline & $(0.111)$ & $(0.057)$ \\
\hline \multirow[t]{2}{*}{ Male (b.Female) } & -0.081 & 0.062 \\
\hline & $(0.147)$ & $(0.103)$ \\
\hline \multirow[t]{2}{*}{ Migrant background (b. Dutch background) } & $-0.448^{* *}$ & -0.056 \\
\hline & $(0.197)$ & $(0.157)$ \\
\hline \multicolumn{3}{|l|}{$\begin{array}{l}\text { Cumulative Covid-19 Cases (Std.) } \\
{ }^{*} \text { Household income quartiles }\end{array}$} \\
\hline \multirow[t]{2}{*}{ 2nd Household income quartile } & $-0.288^{* *}$ & \\
\hline & $(0.118)$ & \\
\hline \multirow[t]{2}{*}{ 3rd Household income quartile } & $-0.249^{* *}$ & \\
\hline & $(0.121)$ & \\
\hline \multirow[t]{2}{*}{ 4th Household income quartile } & $-0.309^{* * *}$ & \\
\hline & $(0.114)$ & \\
\hline \multirow[t]{2}{*}{ Cumulative Covid-19 Cases (Std.)*Populist } & & $0.183^{* *}$ \\
\hline & & $(0.078)$ \\
\hline \multirow[t]{2}{*}{ Constant } & $5.144^{* * *}$ & $5.896^{* * *}$ \\
\hline & $(0.214)$ & $(0.092)$ \\
\hline Between individual variance & 2.715 & 2.351 \\
\hline Within individual variance & 1.131 & 1.047 \\
\hline Observations & 1,276 & 2,206 \\
\hline Groups & 638 & 1,103 \\
\hline Note: & ${ }^{*} p<0.1 ;{ }^{* *} p$ & $5 ;{ }^{* * *} p<0.0$ \\
\hline
\end{tabular}


Table A11. Random effect models with occupation interactions.

\begin{tabular}{|c|c|c|c|c|c|c|c|c|c|c|c|c|c|}
\hline & (1) & (2) & (3) & (4) & $(5)$ & (6) & (7) & (8) & (9) & $(10)$ & $(11)$ & $(12)$ & (13) \\
\hline \multicolumn{14}{|c|}{ (2) } \\
\hline Attends school or is studying & $(0.268)$ & & & & & & & & & & & & \\
\hline \multirow[t]{2}{*}{ Does something else } & & -0.696 & & & & & & & & & & & \\
\hline & & $(0.569)$ & & & & & & & & & & & \\
\hline \multirow[t]{2}{*}{ Pensioner } & & & & -0.211 & & & & & & & & & \\
\hline & & & & $(0.138)$ & & & & & & & & & \\
\hline \multirow[t]{2}{*}{ Paid employment } & & & & & 0.032 & & & & & & & & \\
\hline & & & & & (0.113) & & & & & & & & \\
\hline \multirow[t]{2}{*}{ Performs voluntary work } & & & & & & $0.590^{*}$ & & & & & & & \\
\hline & & & & & & $(0.303)$ & & & & & & & \\
\hline Exempted from job seeking following job loss & & & & & & & & & (0.510) & & & & \\
\hline \multirow[t]{2}{*}{ Has (partial) work disability } & & & & & & & & & & $-0.573^{* *}$ & & & \\
\hline & & & & & & & & & & $(0.230)$ & & & \\
\hline \multirow[t]{2}{*}{ Job seeker following job loss } & & & & & & & & & & & 0.126 & & \\
\hline & & & & & & & & & & & (0.299) & & \\
\hline \multirow[t]{2}{*}{ Performs unpaid work while retaining unemployment benefit } & & & & & & & & & & & & 0.432 & \\
\hline & & & & & & & & & & & & (0.693) & \\
\hline \multirow[t]{2}{*}{ Takes care of the housekeeping } & & & & & & & & & & & & & 0.165 \\
\hline & & & & & & & & & & & & & $(0.185)$ \\
\hline High education (b. low education) & $0.917^{* * *}$ & $0.874^{* * *}$ & $0.870^{* * *}$ & $0.891^{* * *}$ & $0.871^{* * *}$ & $0.864^{* * *}$ & $0.877^{* * *}$ & $0.879^{* * *}$ & $0.870^{* * *}$ & $0.853^{* * *}$ & $0.875^{* * *}$ & $0.873^{* * *}$ & $0.885^{* *}$ \\
\hline
\end{tabular}




\section{Age (Std.)}

Net household income (Std.)

Male (b.Female)

Migrant background (b. Dutch background)

Cumulative Covid-19 Cases (Std.)*Attends school or is studying

Cumulative Covid-19 Cases (Std.)*Does something else

Cumulative Covid-19 Cases (Std.)*First-time job seeker

Cumulative Covid-19 Cases (Std.)*Pensioner

Cumulative Covid-19 Cases (Std.)*Paid employment

Cumulative Covid-19 Cases (Std.)*Performs voluntary work

Cumulative Covid-19 Cases (Std.)*Works or assists in family business

Cumulative Covid-19 Cases (Std.)*Autonomous professional, freelancer, or self-employed

Cumulative Covid-19 Cases (Std.)*Exempted from job seeking following job loss

Cumulative Covid-19 Cases (Std.)*Has (partial) work disability

Cumulative Covid-19 Cases (Std.)*Job seeker following job loss $\begin{array}{lllllllllllll}(0.105) & (0.105) & (0.105) & (0.106) & (0.105) & (0.105) & (0.105) & (0.105) & (0.105) & (0.105) & (0.105) & (0.105) & (0.106)\end{array}$

$\begin{array}{lllllllllllll}0.057 & -0.036 & -0.031 & 0.041 & -0.024 & -0.043 & -0.033 & -0.035 & -0.033 & -0.039 & -0.032 & -0.032 & -0.037\end{array}$

$\begin{array}{llllllllllllll}(0.058 & (0.053) & (0.053) & (0.069) & (0.059) & (0.053) & (0.053) & (0.053) & (0.053) & (0.053) & (0.053) & (0.053) & (0.053)\end{array}$

$0.149^{* * *} 0.136^{* * *} 0.142^{* * *} 0.134^{* * *} 0.138^{* * *} 0.152^{* * *} 0.140^{* * *} 0.143^{* * *} 0.140^{* * *} 0.130^{* * *} 0.141^{* * *} 0.141^{* * *} 0.139^{* * *}$

$\begin{array}{lllllllllllll}(0.046 & (0.047) & (0.047) & (0.047) & (0.047) & (0.047) & (0.047) & (0.047) & (0.047) & (0.047) & (0.047) & (0.047) & (0.047)\end{array}$

$\begin{array}{lllllllllllll}-0.164 & -0.160 & -0.161 & -0.150 & -0.162 & -0.157 & -0.162 & -0.156 & -0.160 & -0.158 & -0.163 & -0.162 & -0.138\end{array}$

$\begin{array}{lllllllllllllll}0.100 & (0.101) & (0.101) & (0.101) & (0.101) & (0.101) & (0.101) & (0.101) & (0.101) & (0.101) & (0.101) & (0.101) & (0.104)\end{array}$

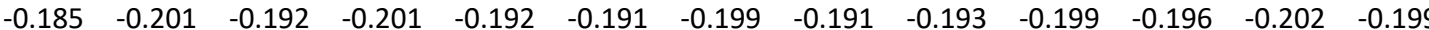

$\begin{array}{lllllllllllllll}(0.139) & (0.139) & (0.139) & (0.139) & (0.139) & (0.139) & (0.139) & (0.139) & (0.139) & (0.139) & (0.139) & (0.140) & (0.139)\end{array}$

$-0.219^{*}$

$(0.123)$

$-0.837^{* *}$

(0.343)

$-0.147$

(0.519)

$0.156^{*}$

(0.067)

$-0.036$

$(0.051)$

$-0.107$

(0.169)

$0.808^{* * *}$

$(0.220)$

$-0.047$

(0.095)

0.068

$(0.294)$

$-0.029$

(0.114)

$-0.243$ 
Cumulative Covid-19 Cases (Std.)*Takes care of the housekeeping

$1,414 \quad 1,41$

1,414

Note: 
Table A12. Random effect models with sector of employment interactions.

\begin{tabular}{|c|c|c|c|c|c|c|c|c|c|c|c|c|c|c|}
\hline & (1) & (2) & (3) & (4) & (5) & (6) & (7) & (8) & (9) & (10) & (11) & (12) & (13) & $(14)$ \\
\hline Cumulative Covid-19 Cases (Std.) & $0.208^{* * *}$ & $0.232^{* * *}$ & $0.211^{* * *}$ & $0.211^{* * *}$ & $0.221^{* * *}$ & $0.199^{* * *}$ & $0.206^{* * *}$ & $0.209^{* * *}$ & $0.210^{* * *} \mathrm{C}$ & $0.170^{* * *}$ & $0.191^{* * *}$ & $0.216^{* * *}$ & $0.210^{* * *}$ & $0.206^{* * *}$ \\
\hline \multicolumn{15}{|l|}{ Sector of employment } \\
\hline Agriculture, forestry, fishery, hunting & $(0.667)$ & & & & & & & & & & & & & \\
\hline \multirow[t]{2}{*}{ Business services (including real estate, rental) } & & 0.328 & & & & & & & & & & & & \\
\hline & & $(0.263)$ & & & & & & & & & & & & \\
\hline \multirow[t]{2}{*}{ Construction } & & & & 0.281 & & & & & & & & & & \\
\hline & & & & (0.398) & & & & & & & & & & \\
\hline \multirow[t]{2}{*}{ Education } & & & & & -0.191 & & & & & & & & & \\
\hline & & & & & $(0.258)$ & & & & & & & & & \\
\hline \multirow[t]{2}{*}{ Environmental services, culture, recreation and other services } & & & & & & 0.027 & & & & & & & & \\
\hline & & & & & & $(0.444)$ & & & & & & & & \\
\hline \multirow[t]{2}{*}{ Healthcare and welfare } & & & & & & & & & -0.039 & & & & & \\
\hline & & & & & & & & & (0.188) & & & & & \\
\hline \multirow[t]{2}{*}{ Industrial production } & & & & & & & & & & -0.015 & & & & \\
\hline & & & & & & & & & & $(0.251)$ & & & & \\
\hline \multirow[t]{2}{*}{ Other } & & & & & & & & & & & -0.037 & & & \\
\hline & & & & & & & & & & & $(0.216)$ & & & \\
\hline \multirow[t]{2}{*}{ Retail trade (including repairs of consumer goods) } & & & & & & & & & & & & 0.436 & & \\
\hline & & & & & & & & & & & & $(0.289)$ & & \\
\hline \multirow[t]{2}{*}{ Transport, storage and communication } & & & & & & & & & & & & & -0.261 & \\
\hline & & & & & & & & & & & & & $(0.323)$ & \\
\hline
\end{tabular}


Utilities production, distribution and/or trade (electricity, natural gas, steam, water)

High education (b. low education)

Age (std.)

Net household income (Std.)

Male (b.Female)

Migrant background (b. Dutch background)

Cumulative Covid-19 Cases (Std.)*Agriculture, forestry, fishery, hunting

Cumulative Covid-19 Cases (Std.)*Business services (including real estate, rental)

Cumulative Covid-19 Cases (Std.)*Catering

Cumulative Covid-19 Cases (Std.)*Construction

Cumulative Covid-19 Cases (Std.)*Education

Cumulative Covid-19 Cases (Std.)*Environmental services, culture, recreation and other services

Cumulative Covid-19 Cases (Std.)*Financia

Cumulative Covid-19 Cases (Std.)*Government services, public administration and mandatory social insurances

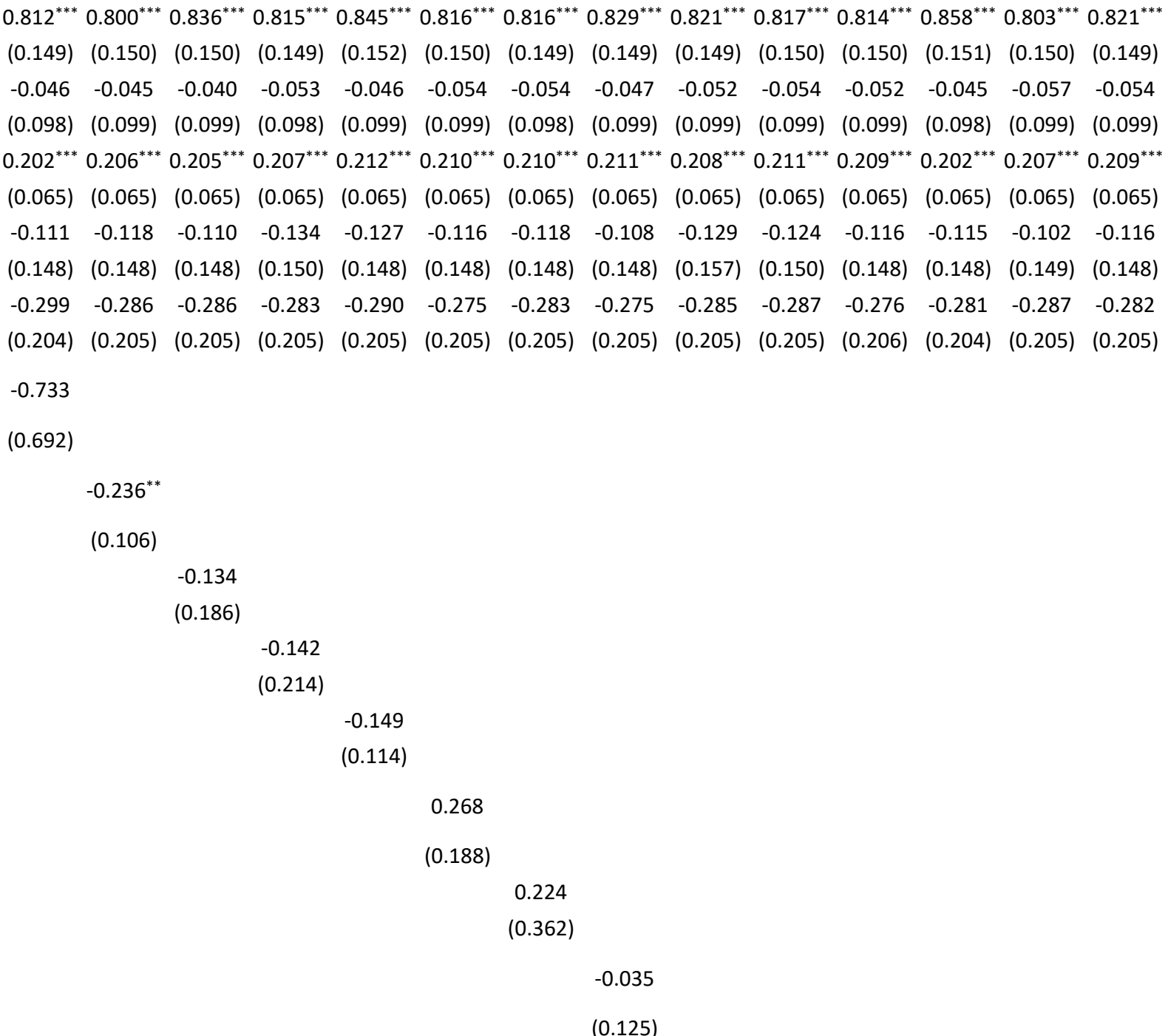

(0.692)

$-0.236^{* *}$

(0.106)

$-0.134$

$0.186)$

$-0.142$

(0.214)

$-0.149$

(0.114)

0.268

(0.188)

0.224

(0.362)

$-0.035$

(0.125) 


2.830

\section{Observations}

$1,2921,292$

Groups

$646 \quad 646$

Note: 
Table A13. Two-way fixed effect model with pre-pandemic trust interaction.

\begin{tabular}{lc}
\hline Cumulative Covid-19 Cases (Std.) & $1.022^{* * *}$ \\
Net household income (Std.) & $(0.080)$ \\
& -0.102 \\
Net household income (Std.)*Trust in & $(0.085)$ \\
national parliament (Pre-pandemic) & $-0.155^{* * *}$ \\
& $(0.013)$ \\
\hline Observations & 2,934 \\
Groups & 1,467 \\
$\mathrm{R}^{2}$ & 0.102 \\
\hline Note: & ${ }^{*} \mathrm{p}<0.1 ;{ }^{* *} \mathrm{p}<0.05 ;{ }^{* * *} \mathrm{p}<0.01$
\end{tabular}

